\title{
Keseimbangan Kerja dan Kehidupan (Work Life Balanced) Pada Wanita Bekerja
}

\author{
T.Elfira Rahmayati \\ Universitas Amir Hamzah \\ elfiramail@gmail.com
}

\begin{abstract}
Abstrak
Peran wanita sebagai pekerja telah memberikan kontribusi yang nyata dalam perkembangan ekonomi dan sosial. Wanita memiliki peluang yang sama untuk hadir dalam dunia kerja setara dengan laki-laki. Akan tetapi bagi para wanita khususnya yang telah menikah hal ini menjadi sebuah tantangan karena mereka harus melakukan banyak tugas di rumah dan juga kantor. Tekanan kerja yang terus meningkat berdampak pada pekerjaan wanita, dimana wanita meninggalkan lebih sedikit waktu untuk diri mereka sendiri. Dengan demikian, mencapai keseimbangan kehidupan kerja adalah kebutuhan bagi wanita bekerja untuk memiliki kualitas hidup yang baik. Penelitian ini menggunakan metode kualitatif dengan pendekatan studi kasus instrumental tunggal. Karakteristik subjek penelitian ini adalah satu orang wanita karir, yaitu subjek $\mathrm{N}$ yang berusia kurang lebih 26 tahun yang berprofesi sebagai Pegawai Negeri Sipil di kota Medan yang bekerja kurang lebih 3 Tahun dan baru memiliki seorang anak dengan usia kurang dari 6 bulan dengan suami yang tinggal di kota berbeda. Teknik pengumpulan data yang digunakan dalam penelitian ini adalah wawancara dan observasi. Berdasarkan hasil penelitian, subjek $\mathrm{N}$ meskipun ada beberapa kesulitan, namun sudah mulai dapat menyeimbangkan antara kehidupan dan pekerjaan yang dilakukan dengan adanya bantuan keluarga. Keberhasilaan subjek N melewati hariharinya mencapai Work Life Balanced terlihat dari pemenuhan aspek time balance, involvement balance, dan satisfaction balance yang pelan-pelan dapat diatasi. Dalam menuju pencapaian tersebut ada beberapa strategi yang digunakan oleh subjek N terutama strategi Outsourcing dan Techflexing.
\end{abstract}

Kata Kunci: Work Life Balanced, wanita bekerja

\section{PENDAHULUAN}

Peran wanita sebagai pekerja telah memberikan kontribusi yang nyata dalam perkembangan ekonomi dan sosial. Kondisi ekonomi dan tuntutan sosial mendorong wanita 
untuk bisa bersaing dalam dunia kerja. Peluang wanita untuk mendapatkan pengetahuan dan pendidikan tinggi, membuat wanita mampu memiliki ketrampilan dalam dunia kerja. Pendidikan tidak hanya memberdayakan mereka tetapi juga telah memberi perempuan untuk memiliki karier yang kuat. Dengan berkembangnya pengetahuan menjadi keterampilan yang diperlukan di era saat ini para pekerja wanita memiliki peluang yang sama untuk hadir dalam dunia kerja setara dengan laki-laki. Akan tetapi bagi para wanita hal ini memang menjadi sebuah tantangan karena mereka harus melakukan banyak tugas di rumah dan juga kantor.

Khususnya Bagi wanita bekerja yang sudah menikah, mereka memiliki tanggung jawab tambahan dalam mengurus pasangan dan ketika menjadi ibu, mereka harus mengelola perawatan primer anak-anak dan keluarga besar. Dengan demikian, tekanan dalam menjalani karier pun menjadi lebih besar. Upaya wanita pekerja untuk mengintegrasikan, mengatur dan menyeimbangkan berbagai masalah dan kegiatan dalam peran mereka yang berbeda secara bersamaan menempatkan mereka di bawah tekanan yang luar biasa.

Tekanan kerja yang terus meningkat berdampak pada pekerjaan wanita, dimana wanita meninggalkan lebih sedikit waktu untuk diri mereka sendiri. Di era pengetahuan ini, meningkatnya tanggung jawab dan berkembangnya teknologi seperti ponsel canggih, dan teknologi yang berhubungan dengan pekerjaan membuat kehidupan kerja yang terintegrasi dengan kehidupan pribadi juga menciptakan tekanan pada kehidupan pribadi dan profesional. Hal ini dapat Ini mempengaruhi kesejahteraan fisik, emosional dan sosial seseorang. Dengan demikian, mencapai keseimbangan kehidupan kerja adalah kebutuhan bagi wanita bekerja untuk memiliki kualitas hidup yang baik (Raya \& Delina,2013).

Dalam masyarakat yang serba cepat saat ini, profesional sumber daya manusia mencari pilihan untuk memberi dampak positif pada keuntungan organisasi, peningkatkan moral karyawan, mempertahankan karyawan dengan nilai pengetahuan perusahaan, dan mengikuti tren tempat kerja. Bagi mereka yang berpikir bahwa yang utama tujuan dalam hidup adalah untuk bekerja, karir mereka menjadi inti dari kehidupan. Namun, orang memiliki waktu terbatas dan karena itu harus melakukan banyak hal kegiatan lain selain pekerjaannya. Tanpa keseimbangan antara keduanya, banyak kesulitan bisa dialami dalam menjalankan keduanya.

Keseimbangan kehidupan kerja didefinisikan sebagai kemampuan individu untuk memenuhi komitmen pekerjaan dan keluarga mereka, serta tanggung jawab non-pekerjaan 
lainnya dan kegiatan. Keseimbangan kehidupan kerja, selain hubungan antara pekerjaan dan fungsi keluarga, juga melibatkan peran lain dalam bidang kehidupan lainnya. Greenhaus (2002) mendefinisikan keseimbangan kerja-kehidupan sebagai kepuasan dan berfungsi dengan baik di tempat kerja dan di rumah dengan konflik peran yang minimal.

Richard.W (2008) dalam karyanya hasil survei tentang keseimbangan kehidupan kerja di Hong Kong mengutip bahwa ada persentase yang mengkhawatirkan dari responden yang merasa bahwa pekerjaan adalah penyebab masalah kesehatan, khususnya stress dan kurang berolahraga. Masalah kesehatan cenderung menyebabkan lebih rendah produktivitas dan efektivitas pekerja. John.P. (2014) mendapatkan jam kerja yang panjang sekitar lebih dari 10 jam/ hari akan mengakibatkan tingkat produktivitas yang menurun dan mendorong karyawan untuk sering tidak bekerja hingga pindah ke perusahaan lain. Jam kerja yang lama membuat mereka sangat lelah. Hal tersebut menyebabkan terbengkalainya beberapa pekerjaan rumah.

Penelitian ini merupakan penelitian kualitatif dalam upaya untuk melihat gambaran tantangan berat yang dihadapi oleh wanita bekerja dalam menjaga keseimbangan antara kehidupan pribadi dan profesional mereka. Berbagai faktor yang mempengaruhi keseimbangan kehidupan dan kerja pada wanita bekerja yang telah menikah menjadi fokus dalam penelitian ini.

\section{TINJAUAN PUSTAKA}

Keseimbangan pekerjaan dan kehidupan atau Work-life balance didefinisikan sebagai persepsi karyawan terhadap waktu pribadi, perawatan keluarga, dan pekerjaan diintegrasikan dengan konflik peran yang minimal (Clark, 2000; Ungerson \& Yeandle, 2005). Work Llife Balance (WLB) merupakan suatu teori yang menjelaskan bagaimana individu mengatur lingkungan pekerjaan dan keluarga dan batasan diantara keduanya untuk mencapai keseimbangan (Clark, 2000).

Hudson (2005) mengemukakan bahwa Work Life Balanced (WLB) merupakan bentuk kepuasan individu dalam mencapai keseimbangan kehidupan dalam pekerjaannya. Kemudian Tasnim, Hossain, dan Enam menyebutkan bahwa Work Life Balanced merupakan suatu kondisi di mana seseorang dapat berbagi peran serta merasakan adanya kepuasan dalam peran-peran 
tersebut yang terlihat dari rendahnya tingkat konflik pekerjaan-keluarga yang terjadi ketika tuntutan kehidupan kerja menimbulkan masalah dalam memenuhi tuntutan kehidupan keluarga (dalam Pratiwi 2021).

Berdasarkan kerangka kerja-keluarga, studi sebelumnya yang dilakukan oleh Staines (1980) mengungkapkan bahwa kendala yang paling sering dialami antara pekerjaan dan domain keluarga adalah persyaratan bersaing untuk waktu. Menurut Singh dan Khanna (2011), Work-Life Balance adalah konsep luas yang melibatkan penetapan prioritas yang tepat antara pekerjaan (karir dan ambisi) pada satu sisi dan kehidupan (kebahagiaan, waktu luang, keluarga dan pengembangan spiritual) di sisi lain. Frame dan Hartog (2003:4), work-life balance berarti karyawan dapat dengan bebas menggunakan jam kerja yang fleksibel untuk menyeimbangkan pekerjaan atau karyanya dengan komitmen lain seperti keluarga, hobi, seni, studi, dan tidak hanya fokus terhadap pekerjaannya. Menurut Parkes dan Langford (2008), work-life balance merupakan kondisi dimana individu yang mampu berkomitmen dalam pekerjaan dan keluarga, serta bertanggung jawab baik dalam kegiatan non-pekerjaan.

Weckstein (2008) bahwa keseimbangan pekerjaan dan kehidupan adalah sebuah konsep keseimbangan yang melibatkan ambisi atau karir dengan kebahagiaan, waktu luang, keluarga dan pengembangan spiritual. Greenhaus, Collins dan Shaw (Dalam Hudson, 2005) menyatakan bahwa ada tiga komponen keseimbangan yaitu :

1. Time balance (Keseimbangan waktu), Menyangkut jumlah waktu yang diberikan untuk bekerja dan peran di luar pekerjaan.

2. Involvement balance (Keseimbangan keterlibatan), Menyangkut keterlibatan tingkat psikologis atau komitmen untuk bekerja dan di luar pekerjaan.

3. Statisfaction balance (Keseimbangan kepuasan), Tingkat kepuasan dalam pekerjaan maupun di luar pekerjaan.

Sedangkan menurut Fisher, Bulger, dan Smith (2009) ada empat dimensi dari keseimbangan tersebut yaitu :

1. Pekerjaan mengganggu kehidupan individu yaitu sejauh mana pekerjaannya mengganggu kehidupan diluar pekerjaan individu serta kesulitan dalam mengatur waktu diantara pekerjaan dan kehidupannya. 
2. Kehidupan individu mengganggu pekerjaan yaitu sejauh mana pekerjaannya mengganggu kehidupan individu. Ketika seseorang memiliki masalah pribadi apakah dia akan bekerja secara professional atau dia suka membawa masalah pribadi tersebut ke dalam kehidupan pekerjaan

3. Kehidupan individu meningkatkan pekerjaan yaitu sejauh mana kehidupan individu meningkatkan pekerjaannya. Misalnya seseorang yang memiliki emosi positif atau perasaan senang juga akan senang ketika bekerja.

4. Pekerjaan meningkatkan kehidupan individu yaitu sejauh mana pekerjaannya meningkatkan kehidupan individu tersebut. Misalnya seseorang mendapatkan reward ketika bekerja.

Fisher (2006) mengemukakan bahwa terdapat lima strategi dalam membentuk Work Life Balanced antara lain:

1. Alternating

Merupakan strategi yang dilakukan oleh seseorang dengan menyusun kegiatan alternatif, seperti melakukan relaksasi di tengah-tengah pekerjaan yang padat.

2. Outsourcing

Merupakan strategi yang dilakukan oleh seseorang dapat mewakili beberapa pekerjaan yang bersifat sampingan atau menjadi prioritas kedua namun tidak lupa memegang pekerjaan wajibnya.

\section{Bundling}

Merupakan strategi yang dilakukan oleh seseorang untuk melakukan aktivitas secara bersamaan, sebagai contoh menemani anak belajar sambil mengerjakan tugas-tugas kantor.

\section{Tecflexing}

Merupakan strategi yang dilakukan oleh seseorang memanfaatkan kecanggihan teknologi untuk menyelesaikan pekerjaan sehingga waktu yang digunakan bisa lebih fleksibel

\section{Simplifying}

Merupakan strategi yang dilakukan oleh seseorang dalam mengurangi beberapa pekerjaan yang kira-kira kurang diperlukan dan didasari oleh pada kebutuhan, nilai ekonomi, serta keuntungan yang akan diperoleh individu. 


\section{METODE PENELITIAN}

Penelitian ini menggunakan metode kualitatif dengan pendekatan studi kasus instrumental tunggal yakni studi yang dilakukan dengan menggunakan sebuah kasus untuk menggambarkan suatu isu atau perhatian. Peneliti memperhatikan dan mengkaji suatu isu yang menarik perhatian dalam hal ini yaitu fenomena mengenai wanita karir dan menggunakan sebuah kasus sebagai sarana (instrumen) untuk menggambarkannya secara terperinci (Creswell, 2007).

Karakteristik subjek penelitian ini adalah satu orang wanita karir, yaitu subjek N yang berusia kurang lebih 26 tahun yang berprofesi sebagai Pegawai Negeri Sipil di kota Medan yang bekerja kurang lebih 3 Tahun dan baru memiliki seorang anak dengan usia kurang dari 6 bulan dengan suami yang tinggal di kota berbeda. Jumlah subjek dalam penelitian ini sebanyak satu orang didasarkan pada pertimbangan-pertimbangan tertentu, yaitu: sesuai dengan fokus permasalahan yang akan diteliti, lokasi penelitian yang strategis, serta bersedia memberikan informasi yang dibutuhkan oleh peneliti.

Teknik pengumpulan data yang digunakan dalam penelitian ini adalah wawancara dan observasi. wawancara akan dilakukan secara berstruktur dengan menggunakan pedoman wawancara dimana wawancara ini dilakukan langsung kepada subjek. Analisis data pada penelitian ini menggunakan analisis tematik, yaitu berfokus pada analisis rinci pada dimensi dan faktor keseimbangan kerja-kehidupan dari data yang paling relevan dengan pertanyaan penelitian atau memberikan deskripsi yang kaya terhadap data secara keseluruhan.

Reliabilitas data dilakukan melalui pengecekan ulang hasil transkrip verbatim untuk memastikan tidak adanya kesalahan yang dibuat selama proses transkripsi, memastikan tidak ada definisi dan makna yang hilang mengenai kode-kode selama proses coding, dan melakukan pemeriksaan ulang terhadap keterkaitan hasil wawancara dan observasi dan mengumpulkan data selesai untuk mendapatkan kesepakatan data.

\section{HASIL DAN PEMBAHASAN}

Gambaran hasil dan pembahasan penelitian ini memfokuskan pada bagaimana keseimbangan kerja-kehidupan subjek yang ditinjau dari dimensi keseimbangan kerja-kehidupan 
menurut Fisher, Bulger, dan Smith (2009) dengan empat dimensi pembentuknya dan beberapa faktor-faktor yang mempengaruhinya.

\subsection{Empat dimensi Keseimbangan Kerja-Kehidupan yaitu :}

\section{Dimensi WIPL (Work Interference With Personal Life)}

Dimensi ini mengacu pada sejauh mana pekerjaan dapat mengganggu kehidupan pribadi individu. Berdasarkan wawancara yang dilakukan kepada subjek $\mathrm{N}$ diketahui untuk dimensi WIPL (Work Interference With Personal Life), subjek $\mathrm{N}$ merasa ada perbedaan ketika bekerja disaat belum menikah dengan saat setelah menikah dan memiliki anak. Kesulitan dirasakan ketika memasuki peran sebagai seorang ibu yaitu dalam pembagian waktu dan mengatasi rasa lelah. Dalam mengurus anak yang saat ini masih bayi subjek merasa masih belum bisa sempurna sehingga setiap pagi ada saja hal-hal yang terkadang menjadi masalah dalam mempersiapkan diri untuk bekerja. Jam kerja yang harus disiplin membuat subjek terkadang harus terburu- buru dan tak jarang ada saja yang tertinggal. Subjek N menyatakan bahwa dirinya sempat stress ketika pertama kali harus bekerja setelah cuti melahirkan karena kesulitan dalam mengatur waktu antara kerja dan mengurus anak apalagi saat ini masih harus memberikan ASI dan subjek juga harus mandiri karena suami bekerja dikota yang berbeda. Pekerjaan yang mulai memakan waktu banyak membuat subjek harus ekstra tenaga untuk bisa mengatur waktu dalam merawat anak yang pada akhirnya subjek harus meminta bantuan kepada ibunya untuk dapat merawat anak selama jam kerja dan selanjutnya perawatan anak setelah jam kerja dilakukan oleh subjek sendiri dengan begitu subjek juga sempat merasa tidak memiliki waktu untuk dirinya sendiri seperti sebelum subjek memiliki anak. Tak jarang awalnya subjek merasa lelah dan terpancing emosi saat anak menangis dan ikut menangis ketika merasa bingung dengan keadaan. Namun seiring berjalannya waktu, saat ini dengan bantuan ibu dan keluarga subjek $\mathrm{N}$ sudah lebih dapat mengatur waktu dan emosi lebih baik.

Berdasarkan pendapat Fisher, Bulger, dan Smith (2009) bahwa keseimbangan kerja- kehidupan dapat diukur dari sejauh mana pekerjaan dapat mengganggu kehidupan pribadi individu, maka dalam hal ini subjek $\mathrm{N}$ tidak dapat mengatur kehidupan pribadinya ketika terjadi permasalahan dalam pengaturan waktu menyangkut 
pekerjaan. Saat subjek $\mathrm{N}$ merasa sangat lelah maka subjek $\mathrm{N}$ akan merasa lebih sensitive dalam perasaannya yang selalu merasa kerepotan hingga mudah marah dan sedih. Dilihat dari dimensi WIPL maka subjek $\mathrm{N}$ masih belum bisa sempurna dalam mengatur kehidupan pribadi dan pekerjaan dan masih memerlukan bantuan untuk dapat mengatur kehidupan pribadinya ketika terjadi permasalahan pekerjaan.

2. Dimensi PLIW (Personal Life Interference With Work)

Dimensi ini mengacu pada sejauh mana kehidupan pribadi individu mengganggu kehidupan pekerjaannya. Untuk dimensi PLIW ( Personal Life Interference With Work ) berdasarkan hasil wawancara yang dilakukan pada subjek $\mathrm{N}$ menyatakan bahwa kehidupan pribadi subjek tidak menghalangi subjek untuk bekerja dan berkarir. Dalam bekerja subjek $\mathrm{N}$ banyak didukung oleh teman-teman sehingga dalam bekerja tidak begitu membuat masalah. subjek $\mathrm{N}$ tetap bekerja seperti biasanya dan menyelesaikan pekerjaannya di kantor, dan tidak membawa ke rumah, kecuali ada keputusan untuk work from home dari atasan. Subjek $\mathrm{N}$ juga menyatakan bahwa keadaan di tempat bekerja sangat menyenangkan dan memberikan kemudahan untuk ia menyelesainkan masalah dan mengerjakan tugas-tugas yang mendukung karier sehingga subjek tidak terbebani dengan pekerjaan. yang sulit untuk subjek hanya pada bagian jam masuk kerja. Hal ini terkait pada kesulitan subjek dalam mempersipakan kebutuhan anak sebelum berangkat kerja sehingga terkadang harus buru-buru agar tidak terlambat.

Berdasarkan pendapat Fisher, Bulger, dan Smith (2009) bahwa keseimbangan kerjakehidupan mengacu pada sejauh mana kehidupan pribadi individu mengganggu kehidupan pekerjaannya, dalam hal ini di temukan bahwa subjek tidak terganggu dalam pekerjaan yang dikarenakan masalah pribadi. karena subjek dapat menyelesaikan pekerjaannya dan tidak membawa masalah pribadi saat dikantor dan tidak membawa masalah pekerjaan kantor untuk diselesaikan dirumah.

\section{Dimensi PLEW (Personal Life Enhancement Of Work)}

Dimensi ini mengacu pada sejauh mana kehidupan pribadi seseorang dapat meningkatkan performa individu dalam dunia kerja. Untuk dimensi PLEW (Personal Life Enhancement Of Work) subjek $\mathrm{N}$ menyatakan bahwa dukungan suami, dan keluarga membuat subjek merasa aman dan nyaman dalam meninggalkan anak dirumah sudah dapat meningkatkan 
semangatnya dalam bekerja sehingga tidak ada kekwatiran dalam dirinya. Kepercayaan suami terhadap kemampuannya membuat subjek lebih percaya diri dalam menjalankan karier dan mengurus rumah tangga. Meskipun awalnya setelah memiliki anak subjek sempat merasa tidak mampu membagi waktu antara untuk marawat anak dan masuk kerja tepat waktu tapi subjek terus berusaha untuk memperbaiki pengaturan waktu sehingga kemampuannya dalam bekerja terus meningkat dan karier juga ikut meningkat. Dukungan keluarga dan lingkungan kerja membuat subjek lebih memiliki semangat untuk berusaha memiliki prestasi.

Keseimbangan kerja-kehidupan tercapai sejauh mana kehidupan pribadi seseorang dapat meningkatkan performa individu dalam dunia kerja (Fisher, Bulger, dan Smith, 2009), berdasarkan hal tersebut maka dukungan keluarga dan lingkungan kerja subjek $\mathrm{N}$ dalam hal ini berdampak positif, yakni membuat subjek mampu menyelesaikan setiap pekerjaannya. Adanya dukungan dari suami dan keluarga memiliki dampak yang sangat dirasakan karena membuat dirinya bersemangat meningkatkan performa dalam menyelesaikan pekerjaan.

4. Dimensi WEPL (Work Enhancement Of Personal Life)

Dimensi ini mengacu pada sejauh mana pekerjaan dapat meningkatkan kualitas kehidupan pribadi individu. Untuk dimensi WEPL (Work Enhancement Of Personal Life) berdasarkan hasil wawancara yang dilakukan subjek N menyatakan bahwa menjadi PNS adalah sebuah prestasi dan kebanggaan bagi diri dan keluarganya. Subjek N pernah mendapatkan prestasi sebagai 5 besar pegawai terbaik saat diklat pengangkatan PNS. hal ini mempengaruhi kepercayaan diri subjek terhadap kemampuannya dalam bekerja dan kepercayaan dirinya dalam menjalani hari-hari sebagia sebuah pengalaman yang dapat dibagikan kepada keluarga. Dalam bekerja subjek merasa diberikan banyak kemudahan dan juga kesempatan untuk belajar hal-hal yang sebelumnya tidak pernah subjek lakukan seperti manjadi pembawa acara dalam acara kantor, menjadi pembicara dan menjadi panitia dalam setiap kegiatan di kantor. Hal itu menjadi pengalaman yang sangat membantu bagi subjek sehingga dalam kehidupan sehari-hari subjek $\mathrm{N}$ menjadi lebih percaya diri dan memiliki kemampuan lebih baik dalam berbicara kepada orang lain. Subjek N juga merasa bahwa dengan pekerjaan yang ia miliki dan jalani sekarang 
membuat kehidupannya semakin berkualitas baik dari segi ekonomi, maupun sosial dan tidak kehilangan waktu untuk dapat menghabiskan waktu bersama keluarga.

Fisher, Bulger, dan Smith (2009) menyatakan keseimbangan tercapai ketika sejauh mana pekerjaan dapat meningkatkan kualitas kehidupan pribadi individu. Misalnya keterampilan yang diperoleh individu pada saat bekerja, memungkinkan individu untuk memanfaatkan keterampilan tersebut dalam kehidupan sehari-hari. Maka jika dilihat pada dimensi ini subjek $\mathrm{N}$ terlihat dapat meningkatkan kualitas kerjanya kedalam kehidupan pribadinya seperti lebih percaya diri dan juga menjadi lebih mampu untuk berkomunikasi dengan orang lain karena telah terbiasa untuk menjadi pembicara di pekerjaannya.

\subsection{Faktor-Faktor Keseimbangan Kerja-Kehidupan}

Berdasarkan faktor keseimbangan kerja-kehidupan diketahui subjek $\mathrm{N}$ menyatakan bahwa dirinya memiliki semangat kerja dan bertanggung jawab terhadap pekerjaan dan urusan rumah tangga. Subjek N mengusahakan untuk dapat menyesuaikan mana pekerjaan yang harus dilakukan terlebih dahulu dan mengusahakan untuk menjalani pekerjaan dengan baik. Namun subjek N masih merasa kurang mampu untuk menyesuaikan waktu menyiapkan keperluan anak dengan waktu masuk kerja sehingga sering terburu-buru dan sering ada barang yang tertinggal. Dan merasa kelelahan setelah pulang kerja namun harus bisa mengambil alih pengasuhan sehingga waku tidur menjadi berkurang. Jarak suami yang berjauhan membuat subjek N harus berusaha sendiri untuk mengendalikan rasa lelah sehingga tidak jarang subjek $\mathrm{N}$ harus meminta bantuan kepada ibu atau keluarga untuk sejenak beristirahat. Dalam perannya sebagai ibu muda, subjek banyak dibantu oleh keluarga. Dalam mengatasi rasa lelahnya subjek masih dapat menggunakan hari 2 hari liburnya setiap minggu untuk sejenak melakukan kegiatan menyenangkan bersama anak. Hal ini lah yang membuat subjek puas menjalani hari-harinya menjadi seorang ibu.

Kesimpulannya dalam aspek keseimbangan waktu, subjek N cukup kesulitan terhadap waktu antara peran sebagai pekerja dan peran sebagai seorang ibu, namun ia berusaha untuk mengatasi nya dengan meminta bantuan kepada keluarga. Dalam aspek keseimbangan 
psikologis, sebagai ibu muda subjek juga mengalami cukup kesulitan dalam mengatasi rasa lelah dan pemulihan tenaga dari peran sebagai pekerja dan kembali pulang untuk peran mengasuh bayi. Dalam aspek keseimbangan kepuasan individu, subjek merasa cukup puas dengan peran nya sebagai pekerja dan sebagai seorang isteri dan sekaligus menjadi seorang ibu. Hal ini dikarenakan subjek merasa mampu pelan-pelan mengatasi kesulitannya dan merasa banyak sekali dukungan dari pasangan untuk semua fasilitas dan dari keluarga yang membantu.

4.3. Lima strategi dalam membentuk Work Life Balanced yang dilakuakn subjek yaitu:

Dalam mencapai keseimbangan pekerjaan dan kehidupan, subjek $\mathrm{N}$ melakukan strategi Alternating yaitu dengan tetap berkomunikasi dengan teman-teman dan sahabat melalui media sosial, melakukan kegiatan perawatan diri di sela-sela waktu libur serta melakukan perjalanan menyenangkan jika suami ada bersama subjek. Strategi Outsourcing yaitu dilakukan subjek N dengan meminta bantuan kepada ibu untuk merawat bayinya pada saat jam subjek bekerja dan bantuan asisten rumah tangga untuk menyuci pakaian serta bantuan keluarga lainnya jika dibutuhkan. Strategi Bundling tidak terlalu banyak dilakukan oleh subjek N karena tugas pekerjaan selalu ia selesaikan saat bekerja sehingga ketika dirumah subjek $\mathrm{N}$ fokus terhadap pekerjaan rumah. Strategi Techflexing banyak dilakukan oleh subjek N seperti pemanfaatan handphone baik untuk pekerjaan, memesan makanan, pengantaran, pegiriman kebutuhan seharihari, mesin cuci, alat-alat teknologi lainnya yang memudahkan subjek mempersiapkan kebutuhan bayi seperti pemasak nasi, pensteril botol susu, kulkas dan alat lainnya dipersiapkan subjek dan suami untuk dapat mendukung aktivitas sehari-hari. Strategi Simplifying dilakukan subjek dengan membatasi kegiatan berkumpul-kumpul dengan teman-teman dan membatasi diri dari kesibukan di media sosial.

\section{KESIMPULAN}

Berdasarkan hasil penelitian, maka dapat disimpulkan bahwa subjek $\mathrm{N}$ masih memiliki beberapa kesulitan, namun sudah mulai dapat menyeimbangkan antara kehidupan dan pekerjaan 
yang dilakukan dengan adanya bantuan keluarga. Keberhasilaan subjek N melewati hari-harinya mencapai Work Life Balanced terlihat dari pemenuhan aspek time balance, involvement balance, dan satisfaction balance yang pelan-pelan dapat diatasi. Dalam menuju pencapaian tersebut ada beberapa strategi yang digunakan oleh subjek $\mathrm{N}$ terutama Outsourcing dan Techflexing dan komitmen yang kuat bersama dengan suami untuk saling percaya dan mendukung setiap keputusan yang diambil.

\section{DAFTAR PUSTAKA}

Denise Horner Mitnick,2006 "The Impact of Working Women on Work/Life Balance Perspectives", University of Pennsylvania Scholarly Commons.

Clark SC (2000).Work/Family Border Theory: A NewTheory of Work/Family Balance. Human Relations 53(6): 747-770.

Fisher, G., Bulger, C., \& Smith, C. (2009). Beyond Work and Family: A Measure of Work/Nonwork Interference and Enhancement. Journal of Occupational Health Psychology. 14(4), 441-456

Greenhause, J.H., Collins, K.M., \& Shaw, J.D.(2002). The relation between work family balance and quality. Journal of Vocational Behaviour, 510-513.

Hudson. 2005. The Case for Work-Life Balance. The Case for Work/Life Balance:

Closing the Gap Between Policy and Practice.

John, P. (2014). The Productivity of Working Hours. Germany: IZA Discussion Paper

Parkes, L. P., \& Langford, P. H. (2008). Work-life balance or work- lifealignment? A test of the importance of work-life balance for employeeengagement and intention to stay in organisations. Journal of Management \& Organization, 14(3), 267-284.

Pratiwi,I.W, 2021. Work Life Balanced Pada Wanita Karir Yang Telah Berkeluarga. Jurnal Penelitian dan Pengukuran Psikologi, Vol 10 No 1 April 2021.

Jurnal Insitusi Politeknik Ganesha Medan

Juripol, Volume 4 Nomor 2 September 2021 
Richard Welford, Work life balance in Hong Kong: Survey results(April 2008), The University of Hong Kong and CSR Asia.

Raya.P, Delina.W (2013). A study on Work-Life Balance in Working Women. IRACST International Journal of Commerce, Business and Management (IJCBM), ISSN: 23192828 Vol. 2, No.5, October 2013

Singh, P. and Khanna, P. (2011). Work-Life Balance: A Tool for Increased Employee Productivity and Retention. LachooManagement Journal.Vol. 2, No. 2, pp. 188-206.

Virick, M., Lilly, J. D., \& Casper, W. J. (2007). Doing more with less. Career Development International, 12(5), 463-480. DOI: 10.1108/13620430710773772

Weckstein, Stacey Hoffer. 2008. How To Practice The Art Of Life Balance. E-book. Copyright: Stacey Weckstein Hoffer 